\title{
COLLECTIVISM AND RIGHT-WING AUTHORITARIANISM AS PREDICTORS OF ETHNOCENTRIC ATTITUDES: THE MODERATING ROLE OF MAJORITY/MINORITY STATUS
}

\author{
Violeta Petroska-Beshka, PhD \\ Ss. Cyril and Methodius University - Skopje, \\ Faculty of Philosophy - Institute of Psychology, vpbeska@yahoo.com \\ Nikolina Kenig, PhD \\ Ss. Cyril and Methodius University - Skopje, \\ Faculty of Philosophy - Institute of Psychology \\ Biljana Stoilkovska-Blazhevska, PhD \\ Ss. Cyril and Methodius University - Skopje, \\ Faculty of Philosophy - Institute of Psychology
}

\section{Abstract}

Building on several findings on the relationships among collectivism and orientations toward authoritarianism on one hand and collectivism and ethnocentrism on the other, the authors examine the possibility of predicting ethnocentric attitudes on the base of these variables by taking into account the potential moderating role of membership to the ethnic group that has majority or minority status.

The study was conducted with a sample of 777 participants $(49.3 \%$ ethnic Macedonians and $50.7 \%$ ethnic Albanians) from different urban areas in the Republic of Macedonia (34\% from Skopje) at the age range from 18 to 58 ( $M=34.0, S D=10.3)$. All participants responded to self-report questionnaires on ethnocentric attitudes (15-item scale by Neuliep, 2002), right wing authoritarianism (22-item scale by Altemeyer, 2006) and collectivism (10-item scale by Yamaguchi, 1994). 


\section{Seccurity}

A three-step hierarchical multiple linear regression analysis was performed among ethnic Macedonian (as majority group) and ethnic Albanian study participants (as minority group) separately. In the first block, gender was controlled for; in the second and in the third block authoritarianism and collectivism, respectively, were entered in the model. It was found that gender explained small, but significant part in the variability of ethnocentrism among ethnic Macedonian participants $(F(1,355)=5.30$; $\mathrm{p}<.05)$. Authoritarianism accounted for significant $10.6 \%$ in the variance of ethnocentric attitudes $(F(1,354)=42.79 ; p<.01)$, while collectivism was not statistically significant predictor of the explored attitudes in this subsample. Analysis conducted among ethnic Albanians revealed that gender was not significant predictor of ethnocentrism, whereas both authoritarianism and collectivism significantly predicted ethnocentric attitudes $(F(1,332)=7.26 ; p<.01$ and $F(1,331)=8.27 ; p<.01$, respectively). The results were discussed from the perspective of the finding that these studied associations were moderated by majority/minority status.

Keywords: authoritarianism, collectivism, ethnocentrism, majority/minority status

\section{Introduction}

A considerable body of literature shows that there are empirically proved links among ethnocentrism, authoritarianism and inclination towards discrimination, prejudice, and hostility for ethnic or national outgroups (e.g., Altemeyer, 1981; Altemeyer, 2006; Duckitt, 1992; Radkiewitcz, 2016). Based on these findings in the sphere of social psychology, numerous authors have initiated rich debates about these links in the realm of public policy and politics (e.g. Biro, Mihic, Milin, \& Logar, 2002; Kuzio, 2015; McFarland, 2003).

Knowledge about these links has an immense value in predicting important societal outcomes and creating adequate policies in today's growingly diverse world. There are many indications though, that policy makers need more contextualized data instead of generalized findings. This study is an attempt to provide information on these relevant linkages in a country where the two biggest ethnic groups have a history of relations that could be described as tensed, distrustful and distant (Hislope, 2007; 


\section{Securiagues}

Maleska, 2010; Petroska-Beshka \& Kenig, 2009). In doing so, we are considering the social identity theory (SIT) as being a main theoretical frame (Tajfel, 1978). This theory claims that the maintenance of positive group identity results in in-group/out-group bias. These positive in-group (we/us) perceptions versus negative perceptions of outgroups (they/them), produce an opportunity for strengthening social identity and enhancing the own self-esteem. Ethnocentrism might be seen as an element of the ingroup favoritism when the identity group is the ethnic/national one, because it is a net of attitudes expressing the belief that one's own ethnic group is superior to other ethnic groups and that one's cultural standards should be applied universally (Hooghe, 2008).

According to the social identity perspective, when people categorize themselves as members of a group (in our case an ethnic group), their social (ethnic) identity is made salient, they experience depersonalization and perceive themselves as compatible with other ingroup members (Turner, Hogg, Oakes, Reicher, \& Wetherell, 1987). In that way, their personal identity generally dissolves and they act as members of the group, not separate individuals. In these circumstances, people discriminate in favor of the ingroup because they see their ethnic group as more important than outgroups and want to achieve a sense of positive group distinctiveness or relative group superiority. Therefore, self-categorization as an ethnic group member, subsequent depersonalization, and needs for relative group superiority are perceived as prerequisites for emerging ethnocentrism.

There are two major lines of defining ethnocentrism. One describes it as a tendency to view other groups or cultures from the perspective of one's own and to evaluate them according to preconceptions originating in the standards and customs of one's own culture. The other view focuses more on the outcomes of such perception and sees ethnocentrism as tendency to believe in the inherent superiority of one's own ethnic group or culture (Berry, Poortinga, Segall, \& Dansen, 2002). On the other hand, there is empirical evidence that ethnocentrism has intergroup as well as intragroup expressions (Bizumic, Duckitt, Popadic, Dru, \& Krauss, 2009). While intergroup ethnocentrism derives from the belief that the ingroup is more important than outgroups, intragroup ethnocentrism is related to the view that one's own group is more important than its individual members. In whatever way it is conceptualized, ethnocentrism is of great importance for peace scholars because it largely contributes 


\section{Seccurity}

to direct and/or structural forms of violence (Christie, Tint, Wagner \& Winter, 2008; Galtung, 1985).

The constructs described by Hofstede (1980) as dimensions of culture, gain increasing attention not only in the area of cross-cultural psychology, but also in the sphere of organizational sciences, sociology and political science. It is assumed that the cultural differences across a variety of social phenomena, such as political structures, shared preferences and norms and typical behaviors are directly influenced by this dimension (Singelis, Triandis, Bhawuk, \& Gelfand, 1995). The most scrutinized dimension, especially in relation to ethnocentrism, is the one identified as individualism-collectivism. Collectivism is defined as preference for a tightly-knit framework in society in which individuals can expect members of a particular in-group to protect them in exchange for unquestioning loyalty (Hofstede, 2011). In his voluminous research, Hofstede proposes a simple way of measuring the extent to which cultures are collectivistic or individualistically oriented. In 2006, ethnic Macedonians and ethnic Albanians in the Republic of Macedonia have been ranked among the cultures that are highly collectivistic (Кениг, 2006).

Triandis (1998) has argued that members of collectivist cultures are expected to display obvious ethnocentric attitudes. Individuals who live in collectivistic societies are expected to endorse higher ethnocentric attitudes simply because in comparison to individualists, they make sharper distinctions between in-groups and out-groups, whereas among individualists, this distinction is typically weaker (Gelfand, Bhawuk, Nishii \& Bechtold, 2004). One of the consequences is that collectivists are less prone to establishing contacts with out-group members and are more 'anchored' in the position of the group(s) where they belong (e.g. Toharudin, Johan, Jaak, \& Billiet, 2008).

The link between collectivism and authoritarianism has been empirically proved as well. Collectivistic homogenization supports authoritarianism by stressing the interdependence between the self and one's group or community. In addition, collectivistic societies prioritize goals that are based on group norms and articulated by traditional authority figures (Oyserman, Coon, \& Kemmelmeier, 2002).

Ethnocentrism is usually defined as a psychological disposition with twofold outcome. On one hand, usually seen as the "positive" consequence, ethnocentrism helps "patriotism and willingness to sacrifice for one's central group" (Neuliep \& McCroskey, 1997: 389) and serves as a building block in construing and maintaining one's cultural/ethnic identity. On the other, ethnocentrism largely contributes toward 
developing ethnic prejudices and decreases acceptance of out-groups. This is the outcome that provides direct link to authoritarianism.

In his influential theory on authoritarianism, Altemeyer (1981) expressed strong belief that authoritarian individuals, defined as those who adhere firmly to conventional norms and are uncritically submissive to authorities and approve punishing violations of norms, at the same time are "incredibly ethnocentric" (2006: 30). Empirical studies have largely confirmed that authoritarians (high-RWA people) are at the same time highly prejudiced. They accept negative attitudes towards women and LGBT population (e.g., Ekehammar, Akrami \& Araya, 2000; Radkiewicz, 2016; Whitley, 1999) and various ethnic groups (e.g., Akrami, Ekehammar, \& Araya, 2000; Van Hiel \& Mervielde, 2002) and approve penal code violence and wars (Benjamin, 2006).

It is considered that the link between authoritarianism and ethnocentrism is established through the underlying preferences for conservative values. Thus, the attitudes of authoritarians regarding their own nation are loaded with exclusiveness and tendency to preserve the desired homogeneity and purity of the in-group (Radkiewicz, 2016).

Studies have also shown that ethnocentrism may be mediated by different other personal and social variables. For instance, women are less ethnocentric than men (Neuliep, Chaudoir \& McCroskey, 2001; Tordjman-Nebe, 2010) and younger tend to be less ethnocentric too. Lin, Rancer \& Trimbitas (2005) found that historical events and culture may as well mediate differences in the level of ethnocentrism and Swenson and Visgatis (2012) proved that media attention increases ethnocentric attitudes.

Conventionally, the literature of intergroup relations focuses solely on examining the ethnocentrism of the dominant (majority) group. One reason for that is that the consequences of such attitudes in majority groups are treated as more problematic. However, neither theory nor experience offers solid ground to expect less ethnocentrism from minority groups. This study attempts to examine the possibility of predicting ethnocentric attitudes on the base of collectivism and right-wing authoritarianism by taking into account the potential mediating role of membership to the ethnic group that has majority or minority status. 


\section{Method}

\section{Participants}

The sample consisted of 777 participants $(50.8 \%$ ethnic Macedonians and 49.2\% ethnic Albanians) from different urban areas in the Republic of Macedonia (34\% from Skopje) at the age range from 18 to 58 ( $M=34$ and $S D=10.3)$. Half of the respondents were women (52.1\%) and all have completed at least secondary education.

The recruitment was on a voluntarily bases. Previously trained psychology students (ethnic Macedonians and ethnic Albanians) were seeking for participants who would accept to participate and were eligible in accordance with the set of criteria regarding age, ethnicity, place of living and education. The paper and pencil questionnaires were responded anonymously in presence of a field worker responsible for gathering the data.

\section{Instruments}

All participants responded to self-report questionnaires on ethnocentric attitudes: 15-item Ethnocentrism scale (Neuliep, 2002), 22-item Right-wing authoritarianism scale (Altemeyer, 2006) and 10-item scale on collectivism (Yamaguchi, 1994). All of them were administered as 7-point Likert scales. The higher the score, the higher is the presence of measured variable.

Neuliep's Ethnocentrism scale (ETHN) was designed to measure the concept defined as perception that one's own group is superior to others and that it is a central point of reference. The author claims that the items relate to the cultures of different parts of the world and that the expected consistency should be in the range of $r=.80$ .90 . For the purposes of our study this scale was adapted to refer to relations between "our" culture and the cultures of the "other" ethnic groups living in the country. Cronbach alpha coefficient for the adapted Ethnocentrism scale for our sample was $\alpha=0.70$.

Altemeyer has developed several versions of the Right-Wing Authoritarian scale (RWA) which were successfully and widely used to measure a concept that he describes as the closest covariate to (1) submission to the established and socially legitimized authority; (2) intentional desire to cause harm to other persons in the name of that authority; and (3) conventionalism and acceptance of law as the basis for 
morality (Altemeyer, 1981). The instrument has fairly high internal consistency of $\alpha=0.68$, yet beyond the most usually reported values in the literature.

The 10-item Collectivism scale (COL) proposed by Yamagutchi (1994) has been chosen among several well-known instruments that measure the same concept because of its practicality. It is aimed to identify the extent to which individuals endorse collectivistic values, practices and identities. High values in collectivism mean prioritizing group as opposed to individual goals and focusing on things such as fitting into the group, behaving in ways that are line with social norms, group solidarity, and gaining a sense of identity from being part of the group. Considering the number of items, the internal homogeneity of $\alpha=0.61$ is acceptable.

All instruments were prepared both in Macedonian and in Albanian language. The semantic equivalence of these two versions was checked and confirmed by using forward-backward translation performed by two independent Albanian native speakers. The averages on separate items and the inter-item correlations have not detected substantial dissimilarities in how participants with different ethnic backgrounds included in the study responded, suggesting that the same concepts were measured in both groups.

\section{Results}

A three-step hierarchical multiple linear regression analysis was performed among ethnic Macedonian and ethnic Albanian study participants separately ${ }^{197}$ by using the SPSS 17 software. In the first block participants' gender was controlled for; predictor variables authoritarianism and collectivism were entered in the second and in the third model, respectively. The criterion variable was ethnocentric attitudes. The preassumptions for performing regression analysis were tested and confirmed as proper for the both research subsamples.

Basic descriptive statistics of ethnocentric attitudes, authoritarianism and collectivism among ethnic Macedonians and ethnic Albanians are presented in Table 1. On average, ethnic Macedonians are less ethnocentric and reported lower level of right-

\footnotetext{
${ }^{197}$ The analysis was performed with a total number of 692 cases with valid responses provided for all included items.
} 
wing authoritarianism compared to ethnic Albanian counterparts $(t(736)=5.64 ; p<, 01$ and $t(745)=3.46 ; p<, 01)$. The level of collectivistic orientation is equal in both groups.

Table 1. Descriptive statistics and differences of means of study variables in the two subsamples

\begin{tabular}{|c|c|c|c|c|c|c|c|c|c|c|}
\hline & \multicolumn{4}{|c|}{$\begin{array}{l}\text { ethnic Macedonians } \\
\qquad(N=378)\end{array}$} & \multicolumn{4}{|c|}{$\begin{array}{l}\text { ethnic Albanians } \\
\quad(N=377)\end{array}$} & \multirow[t]{2}{*}{$t$} & \multirow[t]{2}{*}{$p$} \\
\hline & M & SD & $X_{\min }$ & $X_{\max }$ & M & SD & $X_{\min }$ & $X_{\max }$ & & \\
\hline $\begin{array}{l}\text { Ethnocentric } \\
\text { attitudes }\end{array}$ & 48.49 & 11.70 & 22 & 84 & 53.03 & 10.81 & 26 & 80 & 5.46 & .000 \\
\hline $\begin{array}{l}\text { Right-wing } \\
\text { authoritarianism }\end{array}$ & 94.09 & 14.68 & 54 & 133 & 97.30 & 11.03 & 57 & 137 & 3.46 & .001 \\
\hline Collectivism & 50.30 & 5.99 & 31 & 65 & 49.10 & 8.06 & 27 & 68 & $-1,84$ & .065 \\
\hline
\end{tabular}

As can be seen from Table 2, hierarchical multiple linear regression analysis revealed that gender explained small $(1.5 \%)$, but significant part in the variability of ethnocentrism among ethnic Macedonian participants (Model $1 ; A 1,355)=5.30 ; p<.05$ ). Females scored lower on ethnocentrism in comparison to males $\left(M_{\mathrm{f}}=47.36\right.$ vs. $\left.M_{m}=50.04 ; \beta=-.121, p<.05\right)$. Authoritarianism accounted for significant $10.6 \%$ in the variance of ethnocentric attitudes (Model $2 ; A 1,354)=42.79 ; p<.001$ ) indicating that study participants with Macedonian ethnic background who reported higher tendency for authoritarianism, have stronger ethnocentric attitudes ( $\beta=.325, p<.001)$. Collectivism was not statistically significant predictor of the explored attitudes in this subsample (Model 3; $F(1,353)=.024 ; p>.05$ ).

Table 2. Hierarchical multiple linear regression analysis performed on the two subsamples

\begin{tabular}{|c|c|c|c|c|c|c|c|c|c|}
\hline & \multirow[b]{2}{*}{ Model } & \multicolumn{4}{|c|}{ Ethnic Macedonians } & \multicolumn{4}{|c|}{ Ethnic Albanians } \\
\hline & & $\beta$ & $\mathrm{t}$ & $\mathrm{R}$ & $\Delta \mathrm{R}^{2}$ & $\beta$ & $\mathrm{t}$ & $\mathrm{R}$ & $\Delta R^{2}$ \\
\hline 1 & Gender & -.121 & $-2.30^{*}$ & .121 & $.015^{*}$ & -.009 & -.17 & .009 & .000 \\
\hline \multirow[t]{2}{*}{2} & Gender & -.107 & $-2.14^{*}$ & & & -.006 & -.11 & & \\
\hline & RWA & .326 & $6.54^{* * * *}$ & .348 & $.106^{* *+4}$ & .146 & $2.69^{* *}$ & .147 & .021 \\
\hline \multirow[t]{3}{*}{3} & Gender & -.107 & $-2.14^{*}$ & & & .000 & .01 & & \\
\hline & RWA & .325 & $6.43^{* * * *}$ & & & .127 & $2.34^{*}$ & & \\
\hline & Collectivism & .008 & .16 & .348 & .000 & .156 & $2.88^{* *}$ & 213 & .024 \\
\hline
\end{tabular}


Results obtained in the ethnic Albanian subsample (Table 2) showed that gender was not significant predictor of ethnocentrism (Model $1 ; f 1,333)=.030 ; p>.05$ ). Authoritarianism significantly predicted ethnocentric attitudes accounting for $2.1 \%$ in the variation in this variable (Model $2 ; F(1,332)=7.26 ; p<.01$ ). Additional significant $2.4 \%$ of the variability in ethnocentric attitudes was explained by collectivistic orientation (Model $3 ; A 1,331)=8.27 ; p<.01$ ). These findings demonstrated that both strongly expressed tendency to authoritarianism and higher collectivistic orientation were related to higher level of ethnocentrism among ethnic Albanian respondents $(\beta=.127, p<.05$ and $(\beta=.156, p<.01$, respectively).

\section{Discussion}

The research highlighted the necessity of understanding the social and cultural context of intergroup relations and the importance of differentiating between individual versus cultural level of analysis in related research. First of all, the obtained results provide evidence that the ethnic Albanians (the minority group) are more ethnocentric than the ethnic Macedonians (the majority group). From the social identity perspective, this finding indicates that, compared to ethnic majority group members, the ethnic minority group members tend to discriminate even more in favor of the ingroup because they see their ethnic group as more important than outgroups and want to achieve a sense of positive group distinctiveness or relative group superiority (Turner et al., 1987).

Additionally, this higher ethnocentrism among ethnic minority group members can be explained as a consequence of the existing competition over resources (LeVine and Campbell, 1972) or even less tangible perceived threats, like group rank, prestige, or status (Tajfel, 1982) that, due to the power difference, is more common for minority than for majority ethnic groups. This finding can be related to the research evidence indicating that people who identify more strongly with a group are more likely to display defensive reactions to social identity threats that make their group look better and make outgroups or the source of the threats look worse (Branscombe $\&$ Wann, 1994; Hewstone, Rubin, \&Willis, 2002). Moreover, this conclusion is supported by results obtained in a previous research carried out by Petroska-Beshka \& Kenig (Петроска-Бешка и Кениг, 2005) that has demonstrated that ethnic Albanians evaluate 
the ingroup as better, more powerful and more active than the outgroup (ethnic Macedonians), whereas the ethnic Macedonians evaluate the ingroup as better, but less active and equally powerful as the outgroup (ethnic Albanians).

Based on the obtained results, it could be concluded that associations between ethnocentrism and the other variables in the study were moderated by majority/minority status. Thus, even though right-wing authoritarianism can predict ethnocentric attitudes of both ethnic Macedonians and ethnic Albanians, its predictive power is evidently higher within the majority than within the minority group. That is, those who tend to be obedient to authorities, to follow them and to respect/admire social norms and traditions, have stronger belief of superiority of their own ethnic group and this relationship is strengthen by affiliation to the majority group in the society.

Collectivism was weak, but significant predictor of ethnocentrism only among participants belonging to the minority ethnic group. In other words, giving importance to group coherency, group goals, significant others' opinion and stronger group identification leads to stronger ethnocentric attitudes in the minority group members, which is not the case among the ethnic majority members. This finding indicates that the intragroup expressions of ethnocentrism, which involve need for group cohesion and ingroup devotion (Bizumic et al., 2009), are more present in the ethnic minority group than in the ethnic majority group.

On the other hand, gender appears to be weak but significant predictor of ethnocentrism in the majority ethnic group where men are more ethnocentric than women, which corresponds with the existing research findings (Neuliep, Chaudoir \& McCroskey, 2001; Tordjman-Nebe, 2010). This is not the case in the minority ethnic group where ethnocentric attitudes are equally dispersed among men and women, not because the ethnic Albanian males are less ethnocentric than the ethnic Macedonian males, but because the ethnic Albanian females are more ethnocentric than the ethnic Macedonian females.

The research has revealed different models for predicting ethnocentrism mediated by the minority/majority status, but did not succeed in detecting the most significant predictors of ethnocentric attitudes in the ethnic minority group that fall beyond the social identity perspective. It suggests that there might be a need to test more potential variables that determine the level of ethnocentrism in ethnic minority groups and further investigate the effects of ethnocentrism in the conflict-dynamics. 
Having in mind that the minority/majority status is determined not only by the share of the ethnic group in the overall population but by the social status of the ethnic group also, the findings of this study cannot be easily generalized outside of the country context. Even though the Albanian ethnic group can be considered as minority in terms of their representation in the country population ( $25 \%$ according to the last Census of 2002), their social position as determined in the legislation and political reality exceeds the status of the minorities in most of the other countries. Additionally, even in terms of numbers, ethnic Albanians are minority at a national level, but at the same time they are majority in certain regions on local level, as well as on the regional level.

\section{References}

1. Akrami, N., Ekehammar, B., \& Araya, T. (2000) "Classical and modern racial prejudice: A study of attitudes toward immigrants in Sweden" in: European Journal of Social Psychology. Vol. 30, pp. 521-532.

2. Altemeyer, B. (1981) Right-wing authoritarianism. Winnipeg: University of Manitoba Press.

3. Altemeyer, B. (2006) The Authoritarians. Winnipeg: University of Manitoba.

4. Benjamin, A. J. (2006) "The relationship between right-wing authoritarianism and attitudes toward violence: Further validation of the attitudes toward violence scale" in: Social Behavior and Personality. Vol. 34, No. 8, pp. 923-926.

5. Berry, J. W., Poortinga, Y. H., Segall, M. H., \& Dansen, P. R. (2002) Crosscultural psychology: Research and applications ( $2^{\text {nd }}$ ed.). New York: Cambridge University Press.

6. Biro, M., Mihic, V., Milin, P. \& Logar, S. (2002) “Did socio-political changes in Serbia change the level of authoritarianism and ethnocentrism of citizens?" in: Psihologija. Vol. 35, No. 1-2, pp. 37-47.

7. Bizumic, B., Duckitt, J., Popadic, D., Dru, V., \& Krauss, S.. (2009) "A crosscultural investigation into a reconceptualization of ethnocentrism" in: European Journal of Social Psychology. Vol. 39, 871-899. 
8. Christie, D. J., Tint, B. S., Wagner, R. V., \& Winter, D. D. (2008) "Peace psychology for a peaceful world" in: American Psychologist. Vol. 63, pp. 540552.

9. Galtung, J. (1985) "Twenty-Five Years of Peace Research: Ten Challenges and Some Responses" in: Journal of Peace Research. Vol. 22, No. 2, 141-158.

10. Gelfand M.J, Bhawuk D.P.S, Nishii L.H, \& Bechtold D.J.. (2004) "Individualism and collectivism". In: Culture, leadership, and organizations: the GLOBE study of 62 societies. Thousand Oaks, CA:Sage Publication, pp.. 437-512

11. Hislope, R. (2007) "From expression to actionable hatred: Ethnic divisions and riots in Macedonia". In: Identity conflicts: Canviolence be regulated?. New Brunswick, London: Transaction Publishers. pp. 149-165.

12. Hofstede, G. (1980) Culture's consequences. Beverly Hills, CA: Sage

13. Hofstede, G. (2011) "Dimensionalizing Cultures: The Hofstede Model in Context" in: Online Readings in Psychology and Culture. http://scholarworks.gvsu.edu, (visited on February $\left.2^{\text {nd }}, 2017\right)$.

14. Hooghe, M. (2008) Ethnocentrism. International Encyclopedia of the Social Sciences. Philadelphia: MacMillan Reference.

15. Ekehammar, B., Akrami, N., \& Araya, T. (2000) "Developmentand validation of Swedish classical and modern sexism scales" in: Scandinavian Journal of Psychology. Vol. 41, pp. 307-314.

16. Кениг, Н. (2006) Хофстедовиот модел на културални димензии: можности за мерење во групен и индивидуален контекст. Необјавена досторска дисертација одбранета на Филозофски факултет, Универзитет „Св. Кирил и Методиј" - Скопје.

17. Kuzio, T. (2015) Nationalism and authoritarianism in Russia: Introduction to the special issue: in: Communist and Post-Communist Studies. http://dx.doi.org/10.1016/j.postcomstud.2015.12.002 (visited on January 12 2017).

18. LeVine, R. A., \& Campbell, D. T. (1972) Ethnocentrism: Theories of conflict, ethnic attitudes, and group behavior. New York: Wiley.

19. Lin, Y., Rancer, A. S. \& Trimbitas, 0. (2005) "Ethnocentrism and interculturalwillingness-to-communicate: $\mathrm{A}$ cross-cultural comparison between Romanian and US American college students" in: Journal of Intercultural Communication. Vol. 34, pp. 138-151. 


\section{Securianues}

20. Maleska, M. (2010) "Interethnic relations in Macedonia: People Centred Analyses" in: New Balkan Politics. Vol. 12, http://www.newbalkanpolitics.org.mk/item/inter-ethnic-relations-inmacedonia:-people-centred-analyses\#.whzcdh3ubok (visited on January 16th, 2017).

21. McFarland, S. (2003) "The effects of authoritarianism and social dominance upon American students' attitudes toward attacking Iraq" in: Psicología Politica. Vol. 27, pp. 119-130.

22. Neuliep, J. W. (2002) "Assessing the Reliability and Validity of the Generalized Ethnocentrism Scale" in: Journal of Intercultural Communication Research. Vol. 31, 201-215.

23. Neuliep, J. W. \& McCroskey, J. C. (1997) "Development of a US and generalized ethnocentrism scale" in: Communication Research Reports. Vol. 14, pp. 385-398.

24. Neuliep, J.W., Chaudoir, M., \& McCroskey, J.C (2001) "A cross-cultural comparison of ethnocentrism among Japanese and United States college students" in: Communication Research Reports. Vol. 18, No. 2, 137-146

25. Oyserman, D., Coon, H. M., \& Kemmelmeier, M (2002) "Rethinking individualism and collectivism: Evaluation of theoretical assumptions and meta-analyses" in: Psychological Bulletin. Vol. 128, pp. 3-72.

26. Петроска-Бешка, В. и Кениг, Н. (2005) "Сликата за сопствениот и за другиот етникум кај македонските и албанските студенти на Педагошкиот факултет во Скопје", во Годишен зборник на Филозофскиот факултет, 58, рр. 87-99.

27. Petroska-Beshka, V. Kenig, N. (2009) "The Ethnic Conflict in Macedonia from the Ethnic Macedonians' Perspective: being Victims in Their Own Country" in: Regional and Ethnic Conflicts: perspectives from the Front Lines. New Jersey: Prentice Hall, pp. 8-17.

28. Radkiewitcz, P. (2016) "Does Authoritarianism Imply Ethnocentric National Attitudes: A Revised Look At The "Authoritarian Triad" And Right-Wing Ideology" in: European Journal of Social Psychology. Vol. 46, pp. 224-236. 


\section{Seccurity}

29. Singelis, T. M., Triandis, H. C., Bhawuk, D. P. S., \& Gelfand, M. J. (1995) "Horizontal and vertical dimensions of individualism and collectivism: A theoretical and measurement refinement" in: Cross-Cultural Research. Vol. 29, No. 3, pp. 240-275.

30. Swenson, T. Visgatis, B. (2012) "Intersections between ethnocentrism and media attention among Japanese and American University Students"

http://www.wilmina.ac.jp/ojc/edu/kiyo_2011/kiyo_08_PDF/d2011_03.pdf (visited on January $20^{\text {th }}, 2017$ )

31. Tajfel, H. (1978) Differentiation between social groups. London: Academic Press.

32. Tajfel, H. (1982) "Social psychology of intergroup relations" in: Annual Review of Psychology. Vol. 33, pp. 1-39.

33. Tordjman-Nebe, T. (2010) "Gender and ethnocentrism in borderlands: how southern Spanish girls and boys represent the Moroccan "other" in: Convergencia, Vol. 17/53, pp. 17-48.

34. Toharudin, T., Johan H.L., Jaak, 0. \& Billiet, B. (2008) "Assessing the relationships between Nationalism, Ethnocentrism, and Individualism in Flanders using Bergstrom's approximate discrete model" in: Statistica Neerlandica. Vol. 62, No. 1, pp. 83-103.

35. Triandis, H.C. (1988) "Collectivism and individualism: A reconceptualization of a basic concept in cross-cultural psychology" in: Personality, attitudes and cognitions. London: Macmillan., pp. 60-95.

36. Turner, J. C., Hogg, M. A., Oakes, P. J., Reicher, S. D., \& Wetherell, M. S. (1987) Re-discovering the social group: A self-categorization theory. Oxford: Basil Blackwell.

37. Van Hiel, A. Mervielde, I. (2002) "Explaining conservative beliefs and political preferences: A comparison of social dominance orientation and authoritarianism" in: Journal of Applied Social Psychology. Vol. 32, pp. 965-976.

38. Yamaguchi, S. (1994) "Collectivism among the Japanese: A perspective from the self" in: Individualism and Collectivism: Theory, Method, and Applications Newbury Park, CA: Sage. pp 175-188.

39. Whitley, B.E. (1999) "Right-wing authoritarianism, social dominance orientation, and prejudice" in: Journal of Personality and Social Psychology. Vol. 77, pp. 126-134. 